\title{
Improving Safety of Shielding Chambers Equipped with Viewing Windows
}

\author{
Oleg A. Kozin and Tatiana A. Kulagina* \\ Siberian Federal University \\ Krasnoyarsk, Russian Federation
}

Received 14.11.2020, received in revised form 25.11.2020, accepted 03.12.2020

\begin{abstract}
The article describes and proves the possibility of increasing the protection against neutron radiation for personnel by means of immersion liquid without major changes in the design of the equipment used and without reducing the safety of the radiation object. Studies of the components properties of the protection glass and the immersion liquid have shown that the properties of the immersion liquid reduce the dose rate of neutron radiation significantly compared to the protection glass, which is used for the main protection against ionizing radiation when working with uraniumplutonium fuels. The use of two-layer protection in viewing windows allows reducing the dose rate of mixed gamma-neutron radiation to values that do not exceed the safe radiation dose for personnel when working with an ionizing radiation source, which in this case is $50 \mathrm{~kg}$ of uranium-plutonium fuel.

Keywords: radiation safety, mixed gamma-neutron radiation, protective box, viewing windows, protection.
\end{abstract}

\section{Повышение безопасности защитных камер, оборудованных смотровыми окнами}

\author{
О.А. Козин, Т.А. Кулагина \\ Сибирский федеральньй университет \\ Российская Федерация, Красноярск
}

Аннотация. Рассмотрена и доказана возможность увеличения защиты от нейтронного излучения на персонал с применением иммерсионной жидкости без серьезных изменений в конструкции используемого оборудования и без снижения безопасности самого радиационного

(C) Siberian Federal University. All rights reserved

This work is licensed under a Creative Commons Attribution-Non Commercial 4.0 International License (CC BY-NC 4.0).

* Corresponding author E-mail address: klv_post@mail.ru 
объекта. Исследования свойств компонентов защитного стекла и иммерсионной жидкости показали, что свойства иммерсионной жидкости значительно уменьшают мощность дозы нейтронного излучения по сравнению с защитным стеклом, которое используется для основной защиты от ионизирующего излучения при работе с уран-плутониевым топливом. Применение двухслойной защиты в смотровых окнах позволяет снизить мощность дозы смешанного гамма-нейтронного излучения до величин, не превышающих безопасной дозы облучения для персонала при работе с источником ионизирующего излучения, которым в данном случае являются 50 кг уран-плутониевого топлива.

Ключевые слова: радиационная безопасность, смешанное гамма-нейтронное излучение, защитный бокс, смотровые окна, защита.

Цитирование: Козин, О.А. Повышение безопасности защитных камер, оборудованных смотровыми окнами / О.А. Козин, Т.А. Кулагина // Журн. Сиб. федер. ун-та. Техника и технологии, 2020. 13(8). С. 956-964. DOI: 10.17516/1999494X-0194

\section{Introduction}

As a rule, all enterprises working with sources of ionizing radiation are equipped with special protection chambers, which provide viewing windows [1-5]. The safety of service personnel is calculated based on the prevention of receiving an increased dose from gamma radiation. It happens due to the fact that before the discovery of the fission reaction, people were guided by known types of radiation - alpha, beta particle fluxes and gamma radiation. These types of radiation occur during radioactive transformations of natural radionuclides in various technological processes [1-3, 5-9].

The device for protection against alpha and beta streams doesn't seem to be difficult, because the penetrating ability of these types of radiation is low. Common materials are used for protection, including transparent ones, such as ordinary silicate or organic glass, which makes it possible to organize the protection of personnel without using special materials successfully [4, 9-11]. In the case of shielding from gamma radiation, it is necessary to take into account its high permeability, using protection from denser materials such as lead, tungsten, iron, etc. [2, 4, 9, 12, 13].

Various combinations of these materials are used in the manufacture of protection chambers for working with ionizing radiation sources. But for visual observation of processes, and sometimes manipulations, the chamber must be equipped with special viewing windows. The viewing windows, just as all enclosing structures, must provide protection from sources of ionizing radiation of service personnel. Such remote work takes place not only in protective boxes, but also in hot cells and other devices with transparent openings that provide radiation protection equivalent to protection made of cast iron with a thickness of 50 to $700 \mathrm{~mm}$. This is sufficient protection against all types of radiation, except neutron radiation, which has the highest penetrating ability [12, 13, 15-17].

The need for protection from neutron radiation resulted from the period when the fission reaction of uranium and plutonium nuclei was discovered accompanied by an intense neutron flux. If you can protect yourself from neutron radiation sources with screens consisting, among other things, of hydrogen-containing substances (such as polyethylene, paraffin, water, etc.) then there are difficulties with the manufacture of viewing windows that reduce the dose from mixed gamma-neutron radiation. These difficulties concern ensuring good visibility of the technological process and at the same time protecting personnel $[4,5,12,13]$. In addition, the disadvantage of hydrogen-containing materials is the fact that they lose transparency quickly and require replacement $[11,12,16,17]$. To ensure the

$$
-957-
$$


protection of personnel, it is necessary to reduce the amount of fissile materials in the boxes, which affects technological processes negatively $[12,13,18,19]$.

Thus, the purpose of this work is to ensure reliable protection of personnel when performing a production task with maximum productivity with a given amount of fissile material.

\section{Calculation of the total dose rate of gamma-neutron radiation}

At mining and chemical combine (Zheleznogorsk), when producing mixed uranium-plutonium fuel, the process box can contain up to $50 \mathrm{~kg}$ of the mixture at the same time in the form of fuel pellets, which content consists of plutonium in the form of $\mathrm{PuO}_{2}$ (the quantity is equal to $20 \%$ ), the rest is uranium. Isotopic composition of plutonium (mass, \%): ${ }^{238} \mathrm{Pu}-2,94 ;{ }^{239} \mathrm{Pu}-57,0 ;{ }^{240} \mathrm{Pu}-23,05 ;{ }^{241} \mathrm{Pu}-$ 10,$77 ;{ }^{242} \mathrm{Pu}-6,24$; isotopic composition of uranium (mass, \%): ${ }^{235} \mathrm{U}-0,925 ;{ }^{238} \mathrm{U}-98,4 ;{ }^{236} \mathrm{U}-0,623$; ${ }^{234} \mathrm{U}-0,002[20]$.

When evaluating radiation factors $[12,13]$, calculations showed that the dose rate of mixed gamma-neutron radiation at a distance of 0.5 meters, taking into account the design of the box, has an unacceptably high value, exceeding the standard value $(12 \mu \mathrm{Sv} / \mathrm{h})$ by 250 times. Neutron radiation was calculated using the formula (1) [13]

$$
Q=\sum \frac{Q_{i} \cdot F}{4 \cdot \pi \cdot R^{2}}
$$

where $Q$ is the flux density, $\mathrm{n} / \mathrm{cm}^{2} \cdot \mathrm{s} ; Q_{0}$ is the partial neutron flux, $\mathrm{n} / \mathrm{s} ; F=e^{-\ln (2) t / T}=e^{-0,693 t / T}-$ coefficient taking into account the change in the total flux density of neutrons due to the decay of a radioactive isotope; and $R$ is the distance from the effective surface of the source, $\mathrm{cm}$.

The conversion of the neutron flux density to the EDR (exposure dose rate) of neutron radiation was performed using the average conversion coefficient calculated from the effective dose per unit fluence under the condition of irradiation with a parallel neutron beam in the anterior-posterior geometry for the neutron energy range from 0.1 to $8 \mathrm{MeV}[13,15]$. The results of calculations of the

Table 1. Calculation of exposure dose rate of neutron radiation from plutonium at $0.5 \mathrm{~m}$ from the radiation source

\begin{tabular}{|c|c|c|c|c|c|c|c|c|c|}
\hline \multirow{2}{*}{ Nuclide } & \multirow{2}{*}{$\begin{array}{c}\text { Isotope } \\
\text { con- } \\
\text { tent, } \%\end{array}$} & \multirow{2}{*}{$\begin{array}{c}\text { Specific } \\
\text { activity, } \\
\text { Bq/g }\end{array}$} & \multirow{2}{*}{$\begin{array}{c}\text { Intensity, } \\
\mathrm{Bq}\end{array}$} & \multicolumn{3}{|c|}{ Neutron radiation, $\mathrm{n} / \mathrm{s} \cdot \mathrm{g}(\mathrm{nuc})$} & \multirow{2}{*}{$\begin{array}{c}\begin{array}{c}\text { Neutron } \\
\text { radiation, } \\
\mathrm{n} / \mathrm{s}\end{array} \\
\mathrm{PuO}_{2}\end{array}$} & \multirow{2}{*}{$\begin{array}{c}\begin{array}{c}\text { Flux } \\
\text { density, } \\
\mathrm{n} / \mathrm{s} \cdot \mathrm{cm}^{2}\end{array} \\
\mathrm{PuO}_{2}\end{array}$} & \multirow{2}{*}{$\begin{array}{c}\text { EDR, } \\
\mu \mathrm{Sv} / \mathrm{h}\end{array}$} \\
\hline & & & & $(\alpha, n)$ & $\begin{array}{c}\text { spontane- } \\
\text { ous }\end{array}$ & total & & & \\
\hline${ }^{238} \mathrm{Pu}$ & 2,94 & $6,34 \mathrm{E}+11$ & $1,64 \mathrm{E}+14$ & $1,38 \mathrm{E}+04$ & $2,50 \mathrm{E}+03$ & $1,63 \mathrm{E}+04$ & $4,22 \mathrm{E}+06$ & $1,13 \mathrm{E}+02$ & $1,40 \mathrm{E}+02$ \\
\hline${ }^{239} \mathrm{Pu}$ & 57 & $2,30 \mathrm{E}+09$ & $1,15 \mathrm{E}+13$ & $3,30 \mathrm{E}+01$ & $2,20 \mathrm{E}-02$ & $3,30 \mathrm{E}+01$ & $1,66 \mathrm{E}+05$ & $5,27 \mathrm{E}+00$ & $6,53 \mathrm{E}+00$ \\
\hline${ }^{240} \mathrm{Pu}$ & 23,05 & $8,44 \mathrm{E}+09$ & $1,71 \mathrm{E}+13$ & $1,26 \mathrm{E}+02$ & $9,00 \mathrm{E}+02$ & $1,03 \mathrm{E}+03$ & $2,08 \mathrm{E}+06$ & $6,61 \mathrm{E}+01$ & $8,20 \mathrm{E}+01$ \\
\hline${ }^{241} \mathrm{Pu}$ & 10,77 & $3,81 \mathrm{E}+12$ & $3,61 \mathrm{E}+15$ & $1,00 \mathrm{E}+00$ & $2,90 \mathrm{E}-02$ & $1,03 \mathrm{E}+00$ & $9,75 \mathrm{E}+02$ & $1,08 \mathrm{E}-02$ & $1,34 \mathrm{E}-02$ \\
\hline${ }^{242} \mathrm{Pu}$ & 6,24 & $1,46 \mathrm{E}+08$ & $8,02 \mathrm{E}+10$ & $1,60 \mathrm{E}+00$ & $1,57 \mathrm{E}+03$ & $1,57 \mathrm{E}+03$ & $8,63 \mathrm{E}+05$ & $2,75 \mathrm{E}+01$ & $3,41 \mathrm{E}+01$ \\
\hline Total & 100 & - & $3,80 \mathrm{E}+15$ & - & - & $2,22 \mathrm{E}+05$ & $7,33 \mathrm{E}+06$ & $2,12 \mathrm{E}+02$ & $2,63 \mathrm{E}+02$ \\
\hline
\end{tabular}

Note: The obtained value of exposure dose rate of neutron radiation from plutonium is equal to $2,63 \cdot 10^{2} \mu \mathrm{Sv} / \mathrm{h}$. 
neutron radiation EDR are shown in Tables 1 and 3, and the gamma radiation EDR are presented in Tables 2 and 4 [12-15].

Table 2. Calculation of exposure dose rate of gamma radiation from plutonium at $0.5 \mathrm{~m}$ from the radiation source

\begin{tabular}{|c|c|c|c|c|c|}
\hline Nuclide & $\begin{array}{c}\text { Isotope } \\
\text { content, } \%\end{array}$ & $\begin{array}{c}\text { Specific activity, } \\
\mathrm{Bq} / \mathrm{g}\end{array}$ & Intensity, $\mathrm{Bq}$ & $\begin{array}{c}\text { Specific dose } \\
\text { rate of gamma } \\
\text { radiation, } \\
\mu \text { Sv/h g-1 h-1 }\end{array}$ & $\begin{array}{c}\text { EDR, } \\
\mu \text { Sv/h }\end{array}$ \\
\cline { 4 - 6 } & 2,94 & $6,34 \mathrm{E}+11$ & $1,64 \mathrm{E}+14$ & $1,81 \mathrm{E}+00$ & $1,87 \mathrm{E}+03$ \\
\hline${ }^{238} \mathrm{Pu}$ & 57 & $2,30 \mathrm{E}+09$ & $1,15 \mathrm{E}+13$ & $1,52 \mathrm{E}-02$ & $3,05 \mathrm{E}+02$ \\
\hline${ }^{239} \mathrm{Pu}$ & 23,05 & $8,44 \mathrm{E}+09$ & $1,71 \mathrm{E}+13$ & $2,60 \mathrm{E}-02$ & $2,11 \mathrm{E}+02$ \\
\hline${ }^{240} \mathrm{Pu}$ & 10,77 & $3,81 \mathrm{E}+12$ & $3,61 \mathrm{E}+15$ & $1,70 \mathrm{E}-01$ & $6,44 \mathrm{E}+02$ \\
\hline${ }^{241} \mathrm{Pu}$ & 6,24 & $1,46 \mathrm{E}+08$ & $8,02 \mathrm{E}+10$ & $8,05 \mathrm{E}-04$ & $1,77 \mathrm{E}+00$ \\
\hline${ }^{242} \mathrm{Pu}$ & 100 & - & $3,80 \mathrm{E}+15$ & - & $3,04 \mathrm{E}+03$ \\
\hline Total & & - & & & $\mathrm{PuO}_{2}$ \\
\hline
\end{tabular}

Note: The obtained value of exposure dose rate of gamma radiation from plutonium is equal to $3,04 \cdot 10^{3} \mu \mathrm{Sv} / \mathrm{h}$.

Table 3. Calculation of exposure dose rate of neutron radiation from uranium at $0.5 \mathrm{~m}$ from the radiation source

\begin{tabular}{|c|c|c|c|c|c|c|c|c|c|}
\hline \multirow{2}{*}{ Nuclide } & \multirow{2}{*}{$\begin{array}{c}\text { Isotope } \\
\text { content, } \\
\%\end{array}$} & \multirow{2}{*}{$\begin{array}{c}\text { Specific } \\
\text { activity, } \\
\text { Bq/g }\end{array}$} & \multirow{2}{*}{$\begin{array}{c}\text { Intensity, } \\
\mathrm{Bq}\end{array}$} & \multicolumn{3}{|c|}{ Neutron radiation, $\mathrm{n} / \mathrm{s} \cdot \mathrm{g}$ (nuc) } & \multirow{2}{*}{$\begin{array}{c}\begin{array}{c}\text { Neutron } \\
\text { radiation, } \\
\mathrm{n} / \mathrm{s}\end{array} \\
\mathrm{UO}_{2}\end{array}$} & \multirow{2}{*}{$\begin{array}{c}\begin{array}{c}\text { Flux } \\
\text { density, } \\
\mathrm{n} / \mathrm{s} \cdot \mathrm{cm}^{2}\end{array} \\
\mathrm{UO}_{2}\end{array}$} & \multirow{2}{*}{$\begin{array}{c}\mathrm{EDR}, \\
\mu \mathrm{Sv} / \mathrm{h}\end{array}$} \\
\hline & & & & $(\alpha, n)$ & $\begin{array}{l}\text { sponta- } \\
\text { neous }\end{array}$ & total & & & \\
\hline${ }^{234} \mathrm{U}$ & 0,002 & $2,32 \mathrm{E}+08$ & $1,63 \mathrm{E}+08$ & $3,00 \mathrm{E}+00$ & $5,02 \mathrm{E}-03$ & $3,01 \mathrm{E}+00$ & $2,12 \mathrm{E}+02$ & $6,73 \mathrm{E}-03$ & $8,35 \mathrm{E}-03$ \\
\hline${ }^{235} \mathrm{U}$ & 0,925 & $8,01 \mathrm{E}+04$ & $2,61 \mathrm{E}+07$ & $7,10 \mathrm{E}-04$ & 2,99E-04 & 1,01E-03 & $3,29 \mathrm{E}+01$ & $1,05 \mathrm{E}-03$ & $1,30 \mathrm{E}-03$ \\
\hline${ }^{236} \mathrm{U}$ & 0,623 & $2,39 \mathrm{E}+06$ & $5,24 \mathrm{E}+08$ & $2,40 \mathrm{E}-02$ & $5,49 \mathrm{E}-03$ & $2,95 \mathrm{E}-02$ & $6,47 \mathrm{E}+02$ & $2,06 \mathrm{E}-02$ & $2,55 \mathrm{E}-02$ \\
\hline${ }^{238} \mathrm{U}$ & 98,45 & $8,44 \mathrm{E}+09$ & $2,92 \mathrm{E}+14$ & $8.30 \mathrm{E}-05$ & $1,36 \mathrm{E}-02$ & $1,36 \mathrm{E}-02$ & $4,71 \mathrm{E}+04$ & $1,50 \mathrm{E}+00$ & $1,86 \mathrm{E}+00$ \\
\hline Total & 100 & - & $2,92 \mathrm{E}+14$ & - & - & $3,05 \mathrm{E}+00$ & $4,80 \mathrm{E}+04$ & $1,53 \mathrm{E}+00$ & $1,90 \mathrm{E}+00$ \\
\hline
\end{tabular}

Note: The obtained value of exposure dose rate of neutron radiation from uranium is equal to $1.9 \mu \mathrm{Sv} / \mathrm{h}$.

Table 4. Calculation of exposure dose rate of gamma radiation from uranium at $0.5 \mathrm{~m}$ from the radiation source

\begin{tabular}{|c|c|c|c|c|c|}
\hline \multirow[t]{2}{*}{ Nuclide } & \multirow[t]{2}{*}{$\begin{array}{c}\text { Isotope } \\
\text { content, \% }\end{array}$} & \multirow[t]{2}{*}{$\begin{array}{c}\text { Specific } \\
\text { activity, } \mathrm{Bq} / \mathrm{g}\end{array}$} & \multirow[t]{2}{*}{ Intensity, Bq } & $\begin{array}{c}\text { Coefficient of effective } \\
\text { dose rate of external } \\
\text { photon irradiation, } \\
\mu \mathrm{Sv} / \mathrm{h} \mathrm{Bq}-1 \mathrm{~h}-1\end{array}$ & $\mathrm{EDR}, \mu \mathrm{Sv} / \mathrm{h}$ \\
\hline & & & & $\mathrm{UO}_{2}$ & $\mathrm{UO}_{2}$ \\
\hline${ }^{234} \mathrm{U}$ & 0,002 & $2,32 \mathrm{E}+08$ & $1,63 \mathrm{E}+08$ & $1,70 \mathrm{E}-10$ & $1,11 \mathrm{E}-01$ \\
\hline${ }^{235} \mathrm{U}$ & 0,925 & $8,01 \mathrm{E}+04$ & $2,61 \mathrm{E}+07$ & $1,61 \mathrm{E}-08$ & $1,68 \mathrm{E}+00$ \\
\hline${ }^{236} \mathrm{U}$ & 0,623 & $2,39 \mathrm{E}+06$ & $5,24 \mathrm{E}+08$ & $1,51 \mathrm{E}-10$ & $3,17 \mathrm{E}-01$ \\
\hline${ }^{238} \mathrm{U}$ & 98,45 & $1,24 \mathrm{E}+04$ & $4,30 \mathrm{E}+08$ & $1,33 \mathrm{E}-10$ & $2,29 \mathrm{E}-01$ \\
\hline Total & 100 & - & $1,14 \mathrm{E}+09$ & - & $2,34 \mathrm{E}+00$ \\
\hline
\end{tabular}

Note: The obtained value of exposure dose rate of gamma radiation from uranium is equal to $2.34 \mu \mathrm{Sv} / \mathrm{h}$.

$$
-959-
$$


The total dose rate of gamma-neutron radiation from $50 \mathrm{~kg}$ of the mixture located in the process box at a distance of 0.5 meters from the radiation source corresponds to $3,3 \cdot 10^{3} \mu \mathrm{Sv} / \mathrm{h}$. To ensure the safe operation of shift personnel, the dose rate of mixed gamma-neutron radiation should be reduced by 250 times $[15,16]$.

\section{The design of the protective screens}

To design protection screens, it is necessary to study the protection properties of the materials used (protection glass and immersion liquid) against neutron radiation. As a protection glass, it is convenient to use lead-free glass that effectively protects against gamma radiation of the following composition:

$$
\begin{aligned}
& \mathrm{BaO}-40-42 \%, \mathrm{Nb}_{2} \mathrm{O}_{5}-0,3-0,9 \%, \mathrm{CeO}_{2}-0,4-0,8 \%, \\
& \mathrm{Sb}_{2} \mathrm{O}_{3}-0,4-1,5 \%, \mathrm{P}_{2} \mathrm{O}_{5}-55-57 \% .
\end{aligned}
$$

The attenuation of neutron radiation by glass components is calculated using the following formula (2) [13]:

$$
J=J_{1} \cdot e^{-\Sigma \cdot x}
$$

where $J$ is the neutron ERD after the screen, $\mu \mathrm{Sv} / \mathrm{h} ; J_{1}$ is the neutron ERD before the screen, $\mu \mathrm{Sv} / \mathrm{h}$; $e$ is the base of the natural logarithm $-2.718 ; \Sigma$ is the macroscopic cross-section of interaction with matter, $\mathrm{cm}^{-1} ; x$ is the screen thickness, $\mathrm{cm}$.

The macroscopic cross section of the interaction of neutrons with matter is calculated by the formula (3) [13]:

$$
\Sigma=\frac{\rho \cdot N_{A}}{M} \cdot\left(n_{1} \cdot \sigma_{1}+n_{2} \cdot \sigma_{2} \ldots\right)
$$

where $\rho$ is the density of the substance, $\mathrm{g} / \mathrm{cm}^{3} ; \mathrm{N}_{\mathrm{A}}$ is the Avogadro number $(6.022 \cdot 1023), \mathrm{mol}^{-1} ; M$ is the mass, $\mathrm{g} / \mathrm{mol} ; \sigma$ is the microscopic cross-section of the element, $\mathrm{cm}^{2} ; n$ is the number of nuclei of the element.

Each compound is calculated separately for multicomponent substances. Then, the results are summarized, taking into account the mass content of components in the substance [13]. Evaluation of macroscopic cross-section of protective glass interaction:

1. $\mathrm{BaO}-40-42 \%, \mathrm{Ba}-89,5 \%, \mathrm{O}-10,5 \%, m=153,32 \mathrm{~g} / \mathrm{mol}, \rho=5,7 \mathrm{~g} / \mathrm{cm}^{3}, \Sigma_{1}=0,042 \mathrm{~cm}^{-1}$;

2. $\mathrm{Nb}_{2} \mathrm{O}_{5}-0,3-0,9 \%, \mathrm{Nb}-69,9 \%, \mathrm{O}-30,1 \%, m=265,8 \mathrm{~g} / \mathrm{mol}, \rho=4,5 \mathrm{~g} / \mathrm{cm}^{3}, \Sigma_{2}=0,033 \mathrm{~cm}^{-1}$;

3. $\mathrm{CeO}_{2}-0,4-0,8 \%, \mathrm{Ce}-81,4 \%, \mathrm{O}-18,6 \%, m=172,11 \mathrm{~g} / \mathrm{mol}, \rho=6,4 \mathrm{~g} / \mathrm{cm}^{3}, \Sigma_{3}=0,055 \mathrm{~cm}^{-1}$;

4. $\mathrm{Sb}_{2} \mathrm{O}_{3}-0,4-1,5 \%, \mathrm{Sb}-83,5 \%, \mathrm{O}-16,5 \%, m=291,5 \mathrm{~g} / \mathrm{mol}, \rho=5,6 \mathrm{~g} / \mathrm{cm}^{3}, \Sigma_{4}=0,127 \mathrm{~cm}^{-1}$;

5. $\mathrm{P}_{2} \mathrm{O}_{5}-55-57 \%, \mathrm{P}-56,4 \%, \mathrm{O}-43,6 \%, m=141,9 \mathrm{~g} / \mathrm{mol}, \rho=2,4 \mathrm{~g} / \mathrm{cm}^{3}, \Sigma_{5}=0,054 \mathrm{~cm}^{-1}$.

The total macroscopic cross-section of the interaction of neutrons with energy of $1 \mathrm{MeV}$ of the protective glass, in accordance with the specific mass fraction of the compound in the substance, will be:

$$
\Sigma_{\text {ст }}=\Sigma_{1} \cdot 0,42+\Sigma_{2} \cdot 0,009+\Sigma_{3} \cdot 0,008+\Sigma_{4} \cdot 0,015+\Sigma_{5} \cdot 0,57=0,049 \mathrm{~cm}^{-1} .
$$

Evaluation of neutron protection by an immersion liquid with good protection properties against both neutron and gamma radiation of the following composition [13]: 
6. $\mathrm{Cd}\left(\mathrm{NO}_{3}\right)_{2}-30 \%, \mathrm{Cd}-47 \%, \mathrm{~N}-13 \%, \mathrm{O}-40 \%, m=236,42 \mathrm{~g} / \mathrm{mol}, \rho=3,6 \mathrm{~g} / \mathrm{cm}^{3}, \Sigma_{6}=0,061 \mathrm{~cm}^{-1}$;

7. $\mathrm{Pb}\left(\mathrm{NO}_{3}\right)_{2}-20 \%, \mathrm{~Pb}-62,5 \%, \mathrm{~N}-8,5 \%, \mathrm{O}-30,0 \%, m=331,5 \mathrm{~g} / \mathrm{mol}, \rho=4,53 \mathrm{~g} / \mathrm{cm}^{3}$, $\Sigma_{7}=0,052 \mathrm{~cm}^{-1}$;

8. $\mathrm{H}_{2} \mathrm{O}-50 \%, \mathrm{H}-11,2 \%, \mathrm{O}-88,8 \%, m=18 \mathrm{~g} / \mathrm{mol}, \rho=1,0 \mathrm{~g} / \mathrm{cm}^{3}, \Sigma_{8}=0,560 \mathrm{~cm}^{-1}$.

The total macroscopic cross-section of the interaction of neutrons with energy of $1 \mathrm{MeV}$ of the immersion liquid, in accordance with the fraction of components, will be:

$$
\Sigma_{ж}=\Sigma_{6} \cdot 0,30+\Sigma_{7} \cdot 0,20+\Sigma_{8} \cdot 0,50=0,309 \mathrm{~cm}^{-1} .
$$

Calculations have shown that the macroscopic cross-section of the interaction of neutrons in the immersion liquid is 6.3 times higher than that of the protection glass, so it became possible to produce an optimal two-component protection to protect personnel from mixed gamma-neutron radiation [15, $16,18]$.

To study the protection properties of the proposed materials, the dependence of neutron radiation attenuation on the thickness of the screens was derived, which showed a higher efficiency of protection against neutron radiation of an immersion liquid compared to glass.

For optimal operating conditions at a distance of $0.5 \mathrm{~m}$ from the source of ionizing radiation, the total protection thickness is no more than $15 \mathrm{~cm}$ (Fig. 2). The most effective protection is when using a two-layer viewing window consisting of glass and an immersion liquid of the same thickness, but then the limit of $15 \mathrm{~cm}$ is not met, so it is more correct to use protection components of different thicknesses $[21,22]$.

The measurements were made by means of DKS-96 device, consisting of the UIK-05 measuring panel, detector BDMG-96 aimed at determining gamma radiation dose rate, detector BDKN-96 aimed at determining neutron radiation dose rate, in accordance with method of measurement MVI-MDGNPPGHK-2016 (No. 01-13.018-2016), which established the procedure for performing calculations of exposure dose rate of gamma and neutron radiation and the flux density of ionizing radiation particles

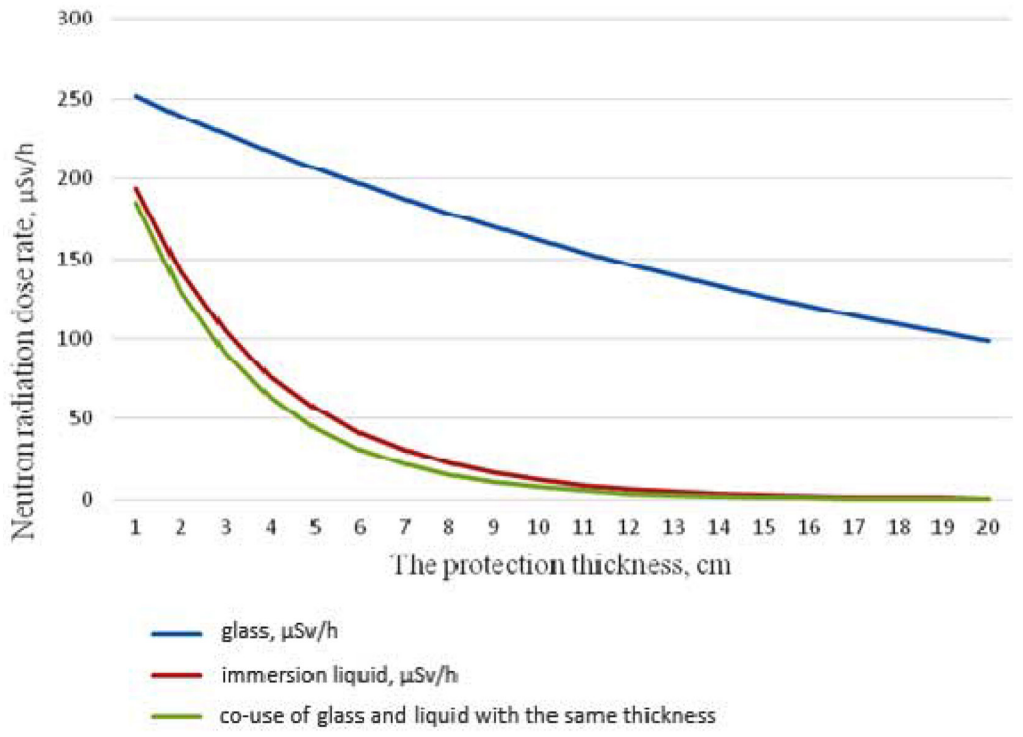

Fig. 1. Comparison of the neutron radiation protection properties of the viewing window components 


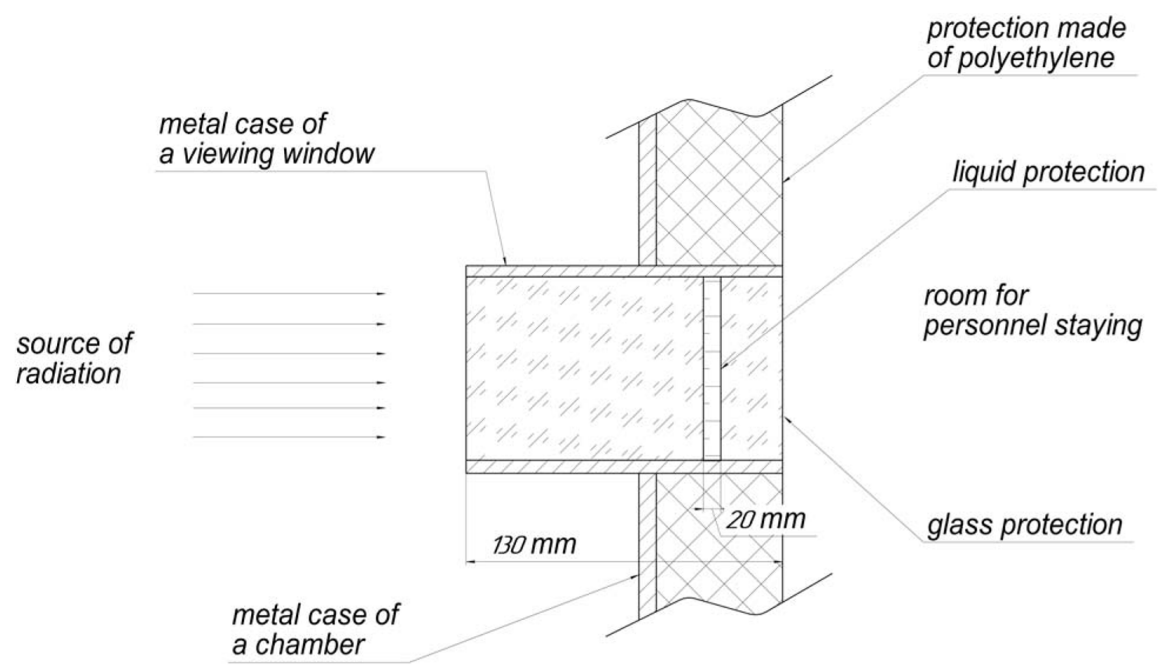

Fig. 2. Protection layers arrangement

Table. 5. Multicomponent protection against mixed gamma-neutron radiation at $0.5 \mathrm{~m}$ from the radiation source

\begin{tabular}{|c|c|c|c|c|}
\hline Product & $\begin{array}{c}\text { EDR from the } \\
\text { radiation source in } \\
\text { the chamber, } \mu \mathrm{Sv} / \mathrm{h}\end{array}$ & $\begin{array}{c}\text { Thickness of the } \\
\text { thickness, } \mathrm{mm} \\
\text { shielding layer } \\
\text { of the immersion } \\
\text { liquid, } \mathrm{mm}\end{array}$ & $\begin{array}{c}\text { EDR after } \\
\text { protection, in the } \\
\text { operator's room, } \\
\mu \mathrm{Sv} / \mathrm{h}\end{array}$ \\
\hline $\begin{array}{c}\text { Mixed uranium- } \\
\text { plutonium fuel, } \\
50 \mathrm{~kg}\end{array}$ & $3,3 \cdot 10^{3}$ & 130 & 20 & 6,2 \\
\hline
\end{tabular}

during radiation monitoring in industrial premises and at the workplaces of personnel [22-25]. The experiment showed high efficiency of protection against mixed gamma-neutron radiation (Table 5) $[11,23]$.

EDR after protection corresponds to $6.2 \mu \mathrm{Sv} / \mathrm{h}$, which is 1.9 times less than the permitted radiation dose rate $(12 \mu \mathrm{Sv} / \mathrm{h})[15,16]$. The proposed protection makes it possible to protect personnel when working with fuel without reducing its amount in the box [20, 23, 24].

\section{Conclusions}

When justifying the manufacture of protection against ionizing radiation based on modern developments, it is necessary to study the properties of materials suitable for successful use in production, which can in turn reduce the cost of manufacturing protection while preserving the shielding properties when working with sources of ionizing radiation.

\section{Acknowledgment}

The reported study was funded by RFBR and the government of Krasnoyarsk region according to the research projects no. 18-48-242001 Thermo physical and hydrodynamic features of the kinetics of mixture formation upon immobilization of radioactive waste in cement matrix using the effects of 
cavitation \& 18-41-242004 Theoretical Foundations of potable water conditioning on the basis of the effects of hydrodynamic cavitation.

\section{References}

[1] Kulagina T.A., Kulagin V.A., Matushenko A.I. Technosphere safety in nuclear power, Krasnoyarsk, Publishing house «Grotesk», SibFU, 2014. 286 p. (in Russian).

[2] Bekman I.N. Atomic and nuclear physics: radioactivity and ionizing radiation, Moscow, Jurayt, 2019, 496 p. (in Russian).

[3] Apollonsky S.M. Protection from physical factors of wave nature. Vol. 2. Protection against ionizing radiation and vibroacoustic vibrations, Moscow, Rusines, 2016, 330 p. (in Russian).

[4] Apollonsky S.M. Protection against ionizing radiation, Moscow, Palmarium Academic Publishing, 2014, 448 p. (in Russian).

[5] Sakharov V.K. Introduction to transport theory and physics of protection against ionizing radiation, Moscow, NNRU MEPhI, 2013, 268 p. (in Russian).

[6] Russell D. Radiation safety, Moscow, VSD, 2013, 582 p. (in Russian).

[7] Shilobreev B.A. Boundary effects in elements of spacecraft onboard equipment under the action of ionizing radiation, Moscow: PHIZMATLIT, 2017, 149 p. (in Russian).

[8] Khala I., Navratil D. Radioactivity, ionizing radiation and nuclear power, Moscow, LKI Publishing house, 2013, 432 p. (in Russian).

[9] Guidelines $M U$ 2.6.5.053-2017. 2.6.5. Nuclear power and industry. Organization of emergency radiation monitoring of external exposure of personnel during work at nuclear-hazardous sites of Rosatom state Corporation enterprises. General requirements. (approved by the FMBA of Russia 11.10.2017) Access from the Internet-legal system «ConsultantPlus» (in Russian).

[10] Guidelines MU 2.6.5.053-2017. 2.6.5. Nuclear power and industry. Organization of emergency radiation monitoring of external exposure of personnel during work at nuclear-hazardous sites of Rosatom state Corporation enterprises. General requirements, (approved by the FMBA of Russia 11.10.2017. Access from the Internet. - legal system «ConsultantPlus» (in Russian).

[11] Guidelines MU 2.6.5.008-2016. 2.6.5. Nuclear energy and industry. Radiation monitoring. General requirements. (approved by FMBA of Russia 22.04.2016), Access from the reference legal system «ConsultantPlus» (in Russian).

[12] Mashkovich V.P., Kudryavtseva A.V. Protection from ionizing radiation, Moscow, Energoatomizdat, 1995, 496 p. (in Russian).

[13] Douglas Riley, Norbert Ensslin, et al. Passive nondestructive analysis of nuclear materials, Moscow, JSC «Binom publishing House», 2000, 720 p. (in Russian).

[14] Kozlov V.F. Handbook of radiation safety, Moscow, Energo-Atomizdat, 1991, 352 p. (in Russian).

[15] Radiation safety standards NRB-99/2009, Sanitary rules and regulations SanPiN 2.6.1.252309, Moscow, Ministry of health of Russia, 2009 (in Russian).

[16] Basic sanitary rules for radiation safety OSPORB-99/2010 Sanitary rules and regulations SP 2.6.1.2612-10. M., Ministry of Health of Russia, 2010 (in Russian).

[17] Panfilov A.P. Evolution of the system for ensuring radiation safety of the country's nuclear industry and its current state. Radiation and risk, 2016. Vol. 25, No. 1, 47-64 (in Russian).

$$
-963-
$$


[18] Kulagina T. ., Kozin O.A., Popkov V.A. Handling of radioactive waste, Krasnoyarsk, Grotesk publishing House, SibFU, 2018, 183 p. (in Russian).

[19] Kulagina T.A., Kozin O.A., Matyushenko A.I. Environmental safety of technosphere objects, Krasnoyarsk, Grotesque publishing House, 2015, 328 p. (in Russian).

[20] NP-058-14 Safety in the management of radioactive waste. General provisions, Moscow, 2014 (in Russian).

[21] Pat. 2605696 Russian Federation, IPC G21F 1/00, polymer-based Material for combined radio and radiation protection / A.A. Boikov, V.V. Cherdyntsev, V.N. Gulbin; applicant and patent holder: FSAEI HE National research technological university «MISaA» Application no. 2015149050/07, 2015.11.17 published in 2016.12.27. Bulletin no. 36 (in Russian).

[22] Pat. 2724977 Russian Federation, IPC G21F 1/00, viewing window for radiation protection chambers of uranium-plutonium fuel production / A.V. Obedin, V.N. Alekseenko, A.S. Dyachenko, A.I. Korobeynikov, P.V. Aksyutin, O.A. Kozin; applicant and patent holder: Federal state unitary enterprise «Mining and chemical combine» (FSUE "MCC"), Application: 2019133090, 16.10.2019, Published: 29.06.2020. Bulletin no.19 (in Russian).

[23] Popova N.P. Research of ionizing radiation, Yekaterinburg, USUPS, 2017, 28 p. (in Russian).

[24] Bolozdynya A.I. Detectors of ionizing particles and radiation. Principles and Applications, Moscow, Intellect, 2019, 763 p. (in Russian).

[25] Kulagina T.A., Kulagin V.A., Popkov V.A. Compounding of spent nuclear fuel, J. Sib. Fed. Univ. Eng. technol., 2016, 9(2), 280-295, DOI: 10.17516/1999-494X-2016-9-2-280-295. 